\title{
Vivere est cogitare. Szkic o dorobku naukowym prof. Marii Zmierczak*
}

\author{
Dla człowieka, który chce zostać wybrany przez lud, \\ głupcy są korporacją szacowną, \\ bo zawsze stanowią większość ${ }^{1}$.
}

Zainteresowania badawcze prof. Marii Zmierczak skupiają się na klasycznych doktrynach politycznych XIX i XX w. oraz wybranych doktrynach prawnych XX w. Wśród tych pierwszych za najdonioślejsze uznać należy badanie historii i ewolucji liberalizmu oraz badania nad faszyzmem i totalitaryzmem. Wśród drugich trzeba wskazać badania renesansu koncepcji prawa natury po II wojnie światowej oraz badania idei państwa prawa. Każdej z tych dziedzin prof. Zmierczak poświęciła część swojej pracy naukowej.

Chronologicznie pierwszym obiektem zainteresowań naukowych prof. Zmierczak była historia i ewolucja myśli liberalnej ze szczególnym uwzględnieniem XIX-wiecznej myśli francuskiej. Tym problemom poświęcony był artykuł z 1973 r. pt. Ideologia liberalna w II Cesarstwie. Uwagi o konfliktach ideowych we Francji w latach 1852-18702. Punktem kulminacyjnym tych badań była opublikowana w 1978 r. monografia pt. Ideologia liberalna w II Cesarstwie francuskim $^{3}$. Za cel rozprawy prof. Zmierczak postawiła sobie nie tylko opis treści ideologii liberalnej, lecz także charakterystykę jej praktycznej roli i scharakteryzowanie zasięgu popularności. Idąc za radą Jeana Toucharda, prof. Zmierczak opisywane idee liberalne umieściła w kontekście historycznym, podejmując próbę

* Sentencja rzymska pochodząca z Rozmów tuskulańskich Cycerona. Całe zdanie brzmi: Loquor enim de docto homine et erudito, cui vivere est cogitare (Mówię bowiem o człowieku uczonym i wykształconym, dla którego żyć to znaczy myśleć).

${ }^{1}$ B. Constant, Dzienniki poufne, Warszawa 1980, s. 236.

2 M. Zmierczak, Ideologia liberalna w II Cesarstwie. Uwagi o konfliktach ideowych we Francji w latach 1852-1870, „Czasopismo Prawno- Historyczne” XXV, 1973, z. 2, s. 119-139.

${ }^{3}$ M. Zmierczak, Ideologia liberalna w II Cesarstwie francuskim, Poznań 1978. 
określenia, ,jak się rodziły i co oznaczały dla ludzi danej epoki”. Wreszcie monografia objęła swą treścią zarówno idee polityczne i prawne, jak i ekonomiczne ${ }^{4}$.

Za doniosły z naukowego punktu widzenia uznać należy także fakt, iż prof. Zmierczak w omawianym dziele zawarła również rozważania dotyczące samego pojęcia liberalizmu oraz jego miejsca w historii doktryn nowożytnych. Wskazała, że liberalizm to zbiór pewnych idei, a także ocen i dyrektyw działania, który był rekonstruowany a posteriori:

ci, którzy głosili idee liberalne, zaczęli używać samego określenia „liberalizm” stosunkowo późno; daleko chętniej mówili i pisali o wolności i wolnościach ${ }^{5}$.

Wśród najważniejszych idei, które składają się na treść myśli liberalnej, słusznie prof. Zmierczak wskazała indywidualizm i uznanie autonomii jednostki ludzkiej za wartość samą w sobie. Ten indywidualizm liberalny złączony był nierozerwalnie $\mathrm{z}$ wiarą we wrodzoną dobroć natury ludzkiej, w jej zdolność do samodzielnego dążenia do szczęścia, a przede wszystkim w racjonalizm ludzkiego postępowania ${ }^{6}$. Z kolei racjonalizm i indywidualizm złożyły się na liberalną koncepcję społeczeństwa, które postrzegane było jako suma składających się na nie jednostek. Stąd też w myśli liberalnej uznaje się, że między interesem społecznym a interesem jednostki nie może być sprzeczności, gdyż ten pierwszy to nic innego jak tylko suma interesów jednostek ${ }^{7}$. Powyższe elementy związane były bezpośrednio z koncepcją praw naturalnych, a za filozoficzny punkt wyjścia prof. Zmierczak uznała filozofię utylitaryzmu.

Tak określona myśl wpływała na państwo i prawo. Jak słusznie zauważyła prof. Zmierczak, państwo w ujęciu liberalnym powinno być zorganizowane racjonalnie i nie krępować praw jednostki. Jednocześnie liberalizm postulował konieczność zapewnienia społeczeństwu kontroli nad państwem ${ }^{8}$. Tak określone przesłanki wskazywały filozofom liberalnym rządy parlamentarne jako najlepszy ustrój.

Monografia prof. Zmierczak została bardzo pozytywnie oceniona w środowisku naukowym i doczekała się recenzji w najważniejszych ówczesnych periodykach ${ }^{9}$. Teresa Janasz w „Czasopiśmie Prawno-Historycznym” podkreśliła, że prof. Zmierczak podjęła się „badania na terenie nieomal dziewiczym nie tylko

${ }^{4}$ Ibidem, s. 3-4.

${ }^{5}$ Ibidem, s. 5.

${ }^{6}$ Ibidem, s. 8.

${ }^{7}$ Ibidem, s. 9.

8 Ibidem.

${ }^{9}$ M. Sobolewski, recenzja książki: M. Zmierczak, Ideologia liberalna w II Cesarstwie francuskim, „Państwo i Prawo”, 1979, z. 5, s. 133-136; T. Janasz, recenzja książki: Ideologia liberalna w II Cesarstwie francuskim, „Czasopismo Prawno-Historyczne” XXXI, 1979, z. 2, s. 248-253; K. Jonca, recenzja książki: Ideologia liberalna w II Cesarstwie francuskim, „Ruch Prawniczy, Ekonomiczny i Socjologiczny" XLI, 1979, z. 4, s. 222-225; J. Ziółek, Z badań nad ideologia liberalna, ,Przegląd Humanistyczny” XXIV, 1980, nr 2 (1730), s. 124-127. 
w naszej literaturze naukowej"10. Oceniając warsztat i zebraną literaturę, wskazała, iż autorka skorzystała z obfitej literatury i wykorzystała z dużą sumiennością liczne numery „Revue des deux mondes” z lat 1852-1870, które stanowią znakomite źródło oddające swoisty klimat tamtych czasów ${ }^{11}$. Recenzentka wręcz podkreśliła, że prof. Zmierczak „poznała znakomicie literaturę epoki i o epoce”, przez co miała możność ukazania „panoramy epoki we wszystkich jej barwach i odcieniach, wzajemnie się warunkujących"12.

Prekursorstwo monografii prof. Zmierczak podkreślił także Jan Ziółek w swym artykule recenzyjnym $Z$ badań nad ideologia liberalna (opublikowanym w „Przeglądzie Humanistycznym”), w którym przyznał, że dotychczas brakowało „W naszej literaturze szczegółowych badań nad liberalizmem drugiego cesarstwa francuskiego"13. Recenzent chwalił także autorkę za bardzo wnikliwą analizę terminu ,wolność” w ujęciu liberałów, a samą książkę uznał za ciekawą i potrzebną ${ }^{14}$.

W podobnie pochwalnym tonie recenzję napisał Karol Jonca w „Ruchu Prawniczym, Ekonomicznym i Socjologicznym”. Wskazał tam, że dzieje ideologii liberalnej nie znalazły szerszego odbicia w naszej literaturze, zaś ,zasługą Marii Zmierczak jest zbadanie francuskiej myśli liberalnej, jej najbardziej istotnych części składowych oraz jej funkcjonowania" ${ }^{15}$. Autor recenzji przyznał, że książka „znakomicie" wychwytuje momenty ważne w historii zmieniającego się społeczeństwa francuskiego. W zdaniu kończącym recenzję Jonca pisał: „z przekonaniem stwierdzić trzeba, że otrzymaliśmy książkę cenną i bardzo potrzebną. Maria Zmierczak swym studium, opartym na świetnej znajomości literatury francuskiej, wypełniła lukę w naszej wiedzy o liberalnej ideologii w dobie II Cesarstwa Francuskiego"16.

Nie może dziwić, że również recenzja pióra Marka Sobolewskiego, zamieszczona w „Państwie i Prawie”, była bardzo pozytywna. Autor wskazał, że „książka powinna przyciągnąć uwagę prawników, nie tylko specjalistów historii doktryn, ale także interesujących się powszechną historią państwa i prawa"17. Według niego „praca wyróżnia się pod wieloma względami bardzo korzystni, stanowi istotne novum w literaturze"18. Za jedną z największych zalet książki autor recenzji uznał wybór okresu II Cesarstwa oraz realizację wysuwanego od dawna postulatu badań ideologicznej zawartości prasy i przemówień politycznych, co — jak zaznaczył - skutkowało „ogromem” materiału do zbadania. Ponadto wskazać należy, iż w wielu miejscach recenzji Sobolewski chwalił prof. Zmierczak za trafne

10 T. Janasz, op. cit., s. 250.

${ }^{11}$ Ibidem, s. 249.

12 Ibidem, s. 250.

13 J. Ziółek, op. cit., s. 125.

14 Ibidem, s. 127.

15 K. Jonca, op. cit., s. 223.

16 Ibidem.

${ }^{17}$ M. Sobolewski, op. cit., s. 133.

18 Ibidem, s. 134. 
analizy, m.in. kluczowego dla liberalizmu pojęcia wolności ${ }^{19}$. Wręcz podkreślał, że „niepodobna wyczerpać w tej recenzji wszystkich interesujących wątków rozprawy”20. Recenzje kończy stwierdzenie, iż ,analiza przeprowadzona przez autorkę jest niezwykle bogata, zestawienie przepisów i obfita dokumentacja bardzo cenna" ${ }^{21}$. Podobnie jak w innych recenzjach, także Marek Sobolewski wyraził żal z powodu zbyt małego nakładu.

Badania myśli liberalnej prof. Zmierczak kontynuowała w późniejszym okresie swojej pracy naukowej. Wśród najważniejszych rozpraw w tego zakresu wymienić należy: Jan Jakub Rousseau — rzecznik totalitaryzmu czy liberalnej demokracji? ${ }^{22}$; Francuscy liberałowie XIX wieku o centralizacji, decentralizacji i samorządzie terytorialnym ${ }^{23}$; Prominent Liberals' Attitude towards Democracy ${ }^{24}$; Leonard Trelawney Hobhouse - prekursor liberalizmu społecznego ${ }^{25}$; John Stuart Mill o prawie wyborczym w demokracji - refleksje z perspektywy XXI wieku ${ }^{26}$.

Za wyjątkową działalność naukową prof. Zmierczak uznać należy bogaty zbiór recenzji pozycji naukowych z dziedziny doktryn polityczno-prawnych. Świadczy to o tym, że prof. Zmierczak od początku swej pracy naukowej bacznie i uważnie śledziła postępy nauki w interesujących ją polach badawczych, na bieżąco zaznajamiając się z najnowszymi wynikami badań naukowych w Polsce i zagranicą. W sferze historii i ewolucji liberalizmu wskazać należy na recenzje tak ważnych i doniosłych dzieł, jak: pierwsze wydanie w języku polskim Dawnego ustroju i rewolucji Alexisa de Tocqueville'a ${ }^{27}$; Liberalizm. Myśl polityczna XIX i XX wieku B. Sobolewskiej i M. Sobolewskiego ${ }^{28}$; Benjamin Constant. Doktryna polityczno-prawna na tle epoki W. Szyszkowskiego ${ }^{29}$; John Stuart Mill.

19 Ibidem, s. 135.

20 Ibidem.

${ }^{21}$ Ibidem, s. 136.

${ }^{22}$ M. Zmierczak, Jan Jakub Rousseau — rzecznik totalitaryzmu czy liberalnej demokracji?, „Czasopismo Prawno-Historyczne” XLI, 1989, z. 2, s. 1-16.

${ }^{23}$ M. Zmierczak, Francuscy liberałowie XIX wieku o centralizacji, decentralizacji i samorzadzie terytorialnym, [w:] Gospodarka, administracja, samorzad, red. H. Olszewski, B. Popowska, „Prace WPiA” II, Poznań 1997, s. 623-631.

${ }^{24}$ M. Zmierczak, Prominent Liberals' Attitude towards Democracy, [w:] Liberalism. Yesterday and Today, red. K. Kujawińska-Courtney, R.M. Machnikowski, Łódź 1998, s. 53-62.

${ }^{25}$ M. Zmierczak, Leonard Trelawney Hobhouse - prekursor liberalizmu społecznego, „Gdańskie Studia Prawnicze" XX, 2008, s. 437-452.

${ }^{26}$ M. Zmierczak, John Stuart Mill o prawie wyborczym $w$ demokracji - refleksje z perspektywy XXI wieku, „Gdańskie Studia Prawnicze” XXVII, 2012, s. 437-446.

${ }^{27}$ M. Zmierczak, recenzja książki: A. de Tocqueville, Dawny ustrój i rewolucja, „Czasopismo Prawno-Historyczne" XXIII, 1971, z. 2, s. 254-255.

28 M. Zmierczak, recenzja książki: B. Sobolewska, M. Sobolewski, Liberalizm. Myśl polityczna XIX i XX wieku, „Czasopismo Prawno-Historyczne” XXXI, 1979, z. 2, s. 222-225.

${ }^{29}$ M. Zmierczak, recenzja książki: W. Szyszkowski, Benjamin Constant. Doktryna polityczno-prawna na tle epoki, „Państwo i Prawo” 1984, z. 11, s.116-118. 
Studium z dziejów liberalizmu politycznego A. Czarnoty ${ }^{30}$; wyboru tekstów pod redakcją Kazimierza M. Ujazdowskiego pt. V Republika Francuska. Idee, konstytucja, interpretacje $e^{31}$ oraz książki Tocquevillian ideas. Contemporary European Perspectives pod redakcją Zbigniewa Raua i Marka Tracza-Trynieckiego ${ }^{32}$.

Drugim znaczącym polem badawczym, na którym prof. Zmierczak odniosła sukcesy naukowe, są badania ideologii faszyzmu i nazizmu. $\mathrm{W}$ tej dziedzinie prof. Zmierczak skupiła się na analizowaniu różnych teorii tłumaczących faszyzm, rozszerzając swe zainteresowania na problematykę nazizmu i innych faszyzmów europejskich. Punktem kulminacyjnym tych badań była wydana w 1988 r. monografia zatytułowana Spory o istote faszyzmu. Dzieje i krytyka. W przedmowie do niej prof. Zmierczak uzasadniła wybór tematu pracy, słusznie wskazując, że XX w. nie może być „opisany i zrozumiany bez odwołania się do faszyzmu”33. Podkreśliła jednocześnie, że nie są jednak rozstrzygnięte tak podstawowe pytania, jak to, czym faszyzm był, co oznaczał ten termin, co było w nim prawidłowością, a co było przypadkowe, ale nade wszystko, co było jego przyczyną i czy może się powtórzyćc ${ }^{34}$. $\mathrm{W}$ ten sposób prof. Zmierczak za zadanie badawcze uznała odtworzenie ,treści odpowiedzi, jakich udzielono na fundamentalne pytania: co różni faszyzm od innych zjawisk społecznych w odniesieniu do trojakiego rodzaju przedmiotów: ideologii, ruchów i partii politycznych oraz ustrojów państwowych"35.

$\mathrm{W}$ tym miejscu warto przytoczyć fragmenty wyjaśnień, jakie prof. Zmierczak zawarła we wnioskach końcowych, a które odnosiły się do istoty faszyzmu jako ideologii. Prof. Zmierczak wskazała na ,pewien zestaw negacji, wspólny dla faszystów, na pewien zestaw wartości, które są dla nich cenne, i na zestaw celów, do których zmierzają" ${ }^{\prime 3}$. Za pierwszy element uznała nacjonalizm oparty na egzaltacji narodowej wspólnoty. Jak jednak słusznie zauważyła prof. Zmierczak, w wypadku faszyzmu chodziło o:

nacjonalizm drapieżny, połączony z bezwzględną wrogością wobec wszystkiego co obce. Nie musi być oparty na rasizmie czy antysemityzmie, wrogami mogą być Żydzi, Słowianie, masoni — zależnie od sytuacji ${ }^{37}$.

Kolejnym elementem była idea wspólnoty zarówno narodowej, jak i państwowej, która podkreśla „konieczność poświęcenia jednostki dla tej wspól-

${ }^{30}$ M. Zmierczak, recenzja książki: A. Czarnota, John Stuart Mill. Studium z dziejów liberalizmu politycznego, „Czasopismo Prawno-Historyczne” XXXIX, 1987, z. 2, s. 241-244.

${ }^{31}$ M. Zmierczak, recenzja książki: V Republika Francuska. Idee, konstytucja, interpretacje, red. K.M. Ujazdowski, „Czasopismo Prawno-Historyczne” LXIII, 2011, z. 2, s. 442-444.

32 M. Zmierczak, recenzja książki: Tocquevillian ideas. Contemporary European Perspectives, red. Z. Rau, M. Tracz-Tryniecki, „Czasopismo Prawno-Historyczne” LXVI, 2014, z. 2, s. 403-406.

${ }^{33}$ M. Zmierczak, Spory o istotę faszyzmu. Dzieje i krytyka, Poznań 1988, s. 5.

34 Ibidem.

35 Ibidem.

36 Ibidem, s. 268.

37 Ibidem, s. 269. 
noty”38. Do tego prof. Zmierczak dołożyła zestaw faszystowskich negacji, czyli antyindywidualizm, antykomunizm, antyliberalizm, antykonserwatyzm, antypacyfizm i antyracjonalizm. Wreszcie za istotne uznała, iż:

cechą charakterystyczną idei faszystowskich jest stopienie w niej elementów sprzecznych: rewolucji i kontrrewolucji, odrzucenie przeszłości i zapowiedź stworzenia nowego, ale odwiecznego sytemu wartości, antykapitalizmu, antykomunizmu, elitaryzmu i zarazem poczucia wspólnoty narodowej. Przyswojenie tak rozmaitych elementów wcale nie musiało prowadzić do utraty zwolenników: najważniejsza była wiara, a nie racjonalna analiza ${ }^{39}$.

Obok odpowiedzi na tak postawione pytania badawcze za niezwykle cenny wkład (i absolutnie ponadczasowy) uznać należy także rozważania o przyszłości faszyzmu i próbę odpowiedzi na pytanie, czy może się on powtórzyć. Prof. Zmierczak podkreśliła, że odpowiedź na to pytanie jest uzależniona od tego, jakie elementy uzna się za konstytutywne:

jeśli zgodzimy się, że faszyzm pozostawił po sobie brutalizację życia politycznego, to przejawia się ona m.in. w nadużywaniu tego określenia wobec przeciwników politycznych ${ }^{40}$.

Książka zyskała pozytywne recenzje, które pojawiły się zarówno w czasopismach naukowych ${ }^{41}$, publicystycznych ${ }^{42}$, jak i periodykach zagranicznych ${ }^{43}$. Wiesław Kozub-Ciembroniewicz w swojej recenzji opublikowanej w „Studiach Historycznych” uznał książkę prof. Zmierczak za ,przedsięwzięcie naukowe istotne i zarazem bardzo potrzebne"44. Recenzowaną pozycję uznał za bardzo wartościową z kilku względów:

1) w sposób metodologicznie poprawny zaprezentowano w niej kompleksowo analizę i systematyzację teorii i interpretacji faszyzmu; 2) rozważania Autorki zostały oparte na solidnym fundamencie źródeł i literatury naukowej; 3) struktura monografii w pełni odpowiada syntetycznej formie narracji autorskiej; 4) wykład uwzględnia zarówno kryteria historycznego rozwoju interpretacji faszyzmu, jak i politycznego oraz warsztatowego ich zróżnicowania; 5) Autorka analizując spory o faszyzmie, przedstawia interpretację własną tego zjawiska ze wskazaniem na jego charakterystyczne cechy ${ }^{45}$.

38 Ibidem.
39 Ibidem, s. 270.
40 Ibidem, s. 266.
41 W.T. Kulesza, recenzja książki: Spory o istote faszyzmu, „Państwo i Prawo” 1989, z. 12, s. 115-118; W. Kozub-Ciembroniewicz, recenzja książki: Spory o istote faszyzmu, „Studia Historyczne" 1990, z. 2, s. 334-336.

42 W. Borodziej, Spory o faszyzm, „Polityka”, 2.09.1989, nr 35, s. 11.

43 J. Holzer, Spory o istote faszyzmu (M. Zmierczak), „Jahrbücher für Geschichte Osteuropas” 39, 1991, z. 2, s. 248-249.

44 W. Kozub-Ciembroniewicz, op. cit., s. 334.

${ }^{45}$ Ibidem. 
W podsumowaniu zaś recenzent wyraził nadzieję na szybkie drugie wydanie „,tej wartościowej książki”, która zasługuje na „wnikliwą uwagę historyków i politologów"46.

Kolejna recenzja Sporów o istotę faszyzmu, autorstwa Władysława T. Kuleszy, ukazała się w „Państwie i Prawie”. Recenzent wskazał, iż na „tle prac najwybitniejszych znawców reprezentujących rodzimą naukę z profesorami F. Ryszką, K. Joncą i J.W. Borejszą na czele należy podkreślić pionierski charakter stworzonej przez Autorkę pracy"47. Recenzent podkreślił, iż

oceniając całość studium, należy stwierdzić, że autorka zrealizowała niewątpliwie trzy zasadnicze jego cele. Uzasadniła przede wszystkim, że faszyzm to nie tylko nazwa własna dla wydarzeń, które rozegrały się w 1922 r., ale pojęcie ogóle, oznaczające fenomen właściwy dla dziejów Europy XX w., którego istnienie nie skończyło się latem 1945 r. Dalej przedstawiła rozbudowaną typologię zjawiska obejmującą cechy charakterystyczne ideologii, ruchów i partii oraz ustrojów państwowych kwalifikowanych jako faszystowskie, otwierając tym samym drogę do dalszego objaśniania licznych problemów badawczych w warunkach większej niż dotąd precyzji w sferze aparatury pojęciowej. Dokonała wreszcie wnikliwej rekonstrukcji dziejów poglądów na faszyzm głównie, choć nie tylko, w europejskim kręgu kulturowym w latach 1922-1986 ${ }^{48}$.

Podobnie jak w poprzedniej recenzji, także Kulesza wyraził nadzieję na szybkie drugie wydanie, a w zakończeniu wskazał, iż wymienione przez niego walory „rozstrzygają o wartości tej pionierskiej pracy, której brak był dotąd tak bardzo odczuwalny w rodzimej literaturze przedmiotu"49.

Jak wspominano wcześniej, Spory o istotę faszyzmu doczekały się nawet recenzji w „Polityce”, ówcześnie najważniejszym i najpoczytniejszym periodyku publicystycznym. Włodzimierz Borodziej wskazał w niej, iż „Maria Zmierczak uporządkowała powstałe $\mathrm{w}$ ciągu ostatnich 60 lat interpretacje i wyobrażenia w sposób wzorowy” ${ }^{\text {0 }}$. Podkreślił, iż autorka „znakomicie pokazuje, iż interpretacja zagrożenia uzależniona była nie tylko od wyznawanej przez piszącego ideologii, ale i od całkiem praktycznych wymogów taktyki politycznej" ${ }^{51}$. Recenzja zresztą roi się od dalszych pochwał dla prof. Zmierczak, podkreśla się w niej ogrom pracy, jaka musiała być wykonana (,że Maria Zmierczak przekopała się przez górę opasłych tomów w kilku językach — nie trzeba dodatkowo podkreślać" ${ }^{52}$ ), wskazuje także na nowości, które książka wniosła dla polskiego czytelnika. Włodzimierz Borodziej uznał, że

\footnotetext{
46 Ibidem, s. 336.

${ }^{47}$ W.T. Kulesza, op. cit., s. 117.

48 Ibidem.

49 Ibidem, s. 118.

${ }^{50}$ W. Borodziej, op. cit., s. 11.

51 Ibidem.

52 Ibidem
} 
całość jest przedstawiona czytelnie, kompetentnie, zwięźle i logicznie; w istocie nie tak często czyta się książki historyczne, których autorzy, tak konsekwentnie przemyśleli swój wykład i tak znakomicie potrafili go uporządkowaćs ${ }^{53}$.

$\mathrm{Na}$ koniec autor tekstu recenzyjnego stwierdził, iż książka prof. Zmierczak to „rzecz, której nie powstydziłyby się najlepsze uniwersytety zachodnie" ${ }^{54}$. Tak jak i w innych wypadkach, także tu znajdziemy żal z powodu niskiego nakładu książki.

Obok wspomnianej wyżej monografii, wśród najważniejszych tekstów prof. Zmierczak dotyczących problematyki faszyzmu i nazizmu wymienić należy: Filozofia i historiozofia w pismach Alfreda Rosenberga. Ze studiów nad ideologią nazizmu ${ }^{55}$; O stanie i kierunkach rozwoju marksistowskich badań nad faszyzmem. Kilka uwag na marginesie zbioru „Faschismusforschung. Positionen, Probleme, Polemik" "56; Jednostka a Volk w ideologii nazizmu ${ }^{57}$; Faszyzm a problemy modernizacji. Krytyka amerykańskich teorii lat sześćdziesiątych ${ }^{58}$; Faszyzm w dokumentach Międzynarodówki Komunistycznej z lat 1922-194359; Autoportret faszyzmu. Refleksje na temat dziejów sporu o istotę faszyzmu ${ }^{60}$; Socjaldemokraci a faszyzm. Uwagi o socjaldemokratycznych teoriach faszyzmu z lat 1922-194561; Spory o rolę i miejsce Adolfa Hitlera w historii Niemiec ${ }^{62}$; O rozumieniu terminu ,faszyzm” w powojennej Polsce ${ }^{63}$; Kilka uwag o objaśnianiu faszyzmu w polskich

${ }^{53}$ Ibidem.

54 Ibidem.

${ }^{55}$ M. Zmierczak, Filozofia i historiozofia w pismach Alfreda Rosenberga. Ze studiów nad ideologia nazizmu, „Studia Historica Slavo-Germanica” IX, Poznań 1980, s. 175-203.

${ }^{56} \mathrm{M}$. Zmierczak, O stanie i kierunkach rozwoju marksistowskich badań nad faszyzmem. Kilka uwag na marginesie zbioru „Faschismusforschung. Positionen, Probleme, Polemik”, „Przegląd Zachodni" XXXVI, 1980, nr 5/6, s. 262-274.

${ }^{57}$ M. Zmierczak, Jednostka a Volk w ideologii nazizmu, [w:] Studia z dziejów myśli politycznej w Niemczech w XIX i XX wieku, red. H. Olszewski, Poznań 1982, s. 232-257.

58 M. Zmierczak, Faszyzm a problemy modernizacji. Krytyka amerykańskich teorii lat sześścdziesiatych, [w:] Faszyzm niemiecki z perspektywy pótwiecza. Materiały i studia, red. A. Czubiński, Poznań 1985, s. 79-97.

${ }^{59}$ M. Zmierczak, Faszyzm w dokumentach Międzynarodówki Komunistycznej z lat 1922 1943, „Studia nad Faszyzmem i Zbrodniami Hitlerowskimi” XI, 1986, „Acta Universitatis Wratislaviensis" 765 , s. $25-48$.

${ }^{60}$ M. Zmierczak, Autoportret faszyzmu. Refleksje na temat dziejów sporu o istote faszyzmu, ,Studia nad Faszyzmem i Zbrodniami Hitlerowskimi” XI, 1987, „Acta Universitatis Wratislaviensis” 815, s. 31-50.

${ }^{61}$ M. Zmierczak, Socjaldemokraci a faszyzm. Uwagi o socjaldemokratycznych teoriach faszyzmu z lat 1922-1945, „Studia nad Faszyzmem i Zbrodniami Hitlerowskimi” XII, 1987, „Acta Universitatis Wratislaviensis" 923, s. 87-106.

${ }^{62}$ M. Zmierczak, Spory o role i miejsce Adolfa Hitlera w historii Niemiec, „Przegląd Zachodni" XLVIII, 1992, z. 4, s. 101-117.

${ }^{63}$ M. Zmierczak, O rozumieniu terminu ,faszyzm” w powojennej Polsce, [w:] Historia prawa. Historia kultury. Liber memorialis Vitoldo Maisel dedicatus, red. E. Borkowskia-Bagieńska, H. Olszewski, Poznań 1994, s. 437-449. 
podręcznikach szkolnych z lat 1945-199564; Spory o Adolfa Hitlera w najnowszej literaturze ${ }^{65}$; Przemówienia polityczne Hitlera przed zdobyciem władzy (19251933)66; Pojęcie „socjalizm” $i$,narodowy socjalizm” $w$ mowach agitacyjnych Hitlera w latach 1925-193367; Krytyka demokracji w ideologii Adolfa Hitlera ${ }^{68}$.

Warto wskazać, iż specjalnym zainteresowaniem, obok badania faszyzmu i nazizmu pod kątem ideologii i doktryn politycznych, prof. Zmierczak obdarzyła tematykę prawa i ustroju w filozofii narodowego socjalizmu i faszyzmu. W tym kontekście warto przytoczyć takie artykuły, jak: Faszyzm a prawo ${ }^{69}$; Pozytywizm prawniczy a prawnicy i prawo w Trzeciej Rzeszy — powojenna dyskusja niemieckich historyków i teoretyków prawa o przyczynach upadku prawa $w$ czasach nazizmu ${ }^{70}$; Spory historyków i politologów o ustrój Trzeciej Rzeszy ${ }^{71}$; Refleksje o prawie cywilnym w totalitarnym ustroju III Rzeszy ${ }^{72}$; Prawo w III Rzeszy a standardy kultury prawnej ${ }^{73}$.

Badania nad faszyzmem i nazizmem w naturalny sposób zaowocowały zainteresowaniem się prof. Zmierczak problematyką ideologii systemów totalitarnych. W jednym ze swoich artykułów (Ideologie totalitarne: faszyzm i narodowy socjalizm ${ }^{74}$ ) wskazała, że nie można mówić o jednej ideologii totalitarnej, a jedynie o typie ideologii totalitarnej: ,ideologii typu totalitarnego, wykorzystywanych dla uzasadnienia reżimów totalitarnych, było bardzo wiele, takich jak komunizm,

${ }^{64}$ M. Zmierczak, Kilka uwag o objaśnianiu faszyzmu w polskich podręcznikach szkolnych z lat 1945-1995, „Studia nad Faszyzmem i Zbrodniami Hitlerowskimi” XX, 1997, „Acta Universitatis Wratislaviensis" 1943, s. 354-374.

${ }^{65}$ M. Zmierczak, Spory o Adolfa Hitlera w najnowszej literaturze, „Studia nad Faszyzmem i Zbrodniami Hitlerowskimi” XXVI, 2003, „Acta Universitas Wratilsaviensis” 2532, s. 341-360.

${ }^{66}$ M. Zmierczak, Przemówienia polityczne Hitlera przed zdobyciem władzy (1925-1933), „Rocznik Nauk Politycznych” 2006, nr 1 (9), s. 101-113.

${ }^{67}$ M. Zmierczak, Pojęcie „socjalizm” $i$,narodowy socjalizm” $w$ mowach agitacyjnych Hitlera w latach 1925-1933, „Studia nad Faszyzmem i Zbrodniami Hitlerowskimi” XXIX, 2007, „Acta Universitatis Wratislaviensis" 2962, s. 65-75.

${ }^{68}$ M. Zmierczak, Krytyka demokracji w ideologii Adolfa Hitlera, „Studia nad Faszyzmem i Zbrodniami Hitlerowskimi” XXXII, 2010, „Acta Universitatis Wratislaviensis” 3240, s. 75-92.

${ }^{69}$ H. Olszewski, M. Zmierczak, Faszyzm a prawo, „Ruch Prawniczy, Ekonomiczny i Socjologiczny” XLIV, 1982, z. 3, s. 25-50.

${ }^{70}$ M. Zmierczak, Pozytywizm prawniczy a prawnicy i prawo w Trzeciej Rzeszy - powojenna dyskusja niemieckich historyków i teoretyków prawa o przyczynach upadku prawa $w$ czasach nazizmu, „Studia nad Faszyzmem i Zbrodniami Hitlerowskimi” XXIV, 2001, „Acta Universitatis Wratislaviensis" 2214, s. 5-30.

${ }^{71}$ M. Zmierczak, Spory historyków i politologów o ustrój Trzeciej Rzeszy, [w:] Studia z historii ustroju i prawa. Księga dedykowana Profesorowi Jerzemu Walachowiczowi, red. H. Olszewski, „Prace Wydziału Prawa i Administracji UAM” VII, Poznań 2002, s. 479-486.

${ }^{72}$ M. Zmierczak, Refleksje o prawie cywilnym w totalitarnym ustroju III Rzeszy, [w:] Księga jubileuszowa Profesora Tadeusza Smyczyńskiego, red. M. Andrzejewski et al., Toruń 2008, s. 851-861.

${ }^{73}$ M. Zmierczak, Prawo w III Rzeszy a standardy kultury prawnej, [w:] Nam hoc natura aequum est, red. A. Madeja, H. Olszewski, Toruń 2012, s. 219-235.

${ }^{74}$ M. Zmierczak, Ideologie totalitarne: faszyzm i narodowy socjalizm, [w:] Totalitaryzm a zachodnia tradycja, red. M. Kuniński, Kraków 2006, s. 160-188. 
faszyzm we Włoszech, narodowy socjalizm w Niemczech, maoizm w Chinach"75. Obok wspomnianego wyżej tekstu wśród najważniejszych w tej dziedzinie wymienić należy: Totalitaryzm - faszyzm - hitleryzm. Z historii sporów o genezę $i$ istotę nazizmu w historiografii $R F N^{76}$; Totalitaryzm czy totalitaryzmy? Kłopoty $z$ definiowaniem pojęcia 77 ; Interwencjonizm, totalitaryzm czy ideologizacja gospodarki? Kilka uwag o wtasności i gospodarce w III Rzeszy ${ }^{78}$; Dyktatorzy totalitarni - problemy metodologiczne $e^{79}$.

Także w sferze badawczej faszyzmu, nazizmu i totalitaryzmów prof. Zmierczak jest autorką licznych recenzji zagranicznych pozycji naukowych, by wymienić jedynie książki: La Question nazie: essai sur les interprétations du national-socialisme: 1922-1975 Pierre'a Aycoberry ${ }^{80}$; Das Unrechtsregime. Internationale Forschung über den Faschismus pod redakcją V.U. Büttnera ${ }^{81}$; Hitlers Herrschaft. Vollzug einer Weltanschauung Eberharda Jäckela ${ }^{82}$; Totalitarian and Authoritarian Regimes in Europe. Legacies and Lessons from the Twenieth Century pod redakcją Jerzego Borejszy, Klausa Ziemera i Magdaleny Hułas ${ }^{83}$; Nacjonalizm włoski. Geneza i ewolucja doktryny politycznej (1896-1923) Joanny Sondel-Cedarmas ${ }^{84}$; Vers un profil convergent des fascismes? „Nouveau consensus" et religion politique en Europe centrale, sous la direction de Traian Sandu, Cahiers de la Nouvelle Europe Traiana Sandu oraz Cioran, Eliade, Ionesco: O zapominaniu faszyzmu. Trzech intelektualistów w dziejowej zawierusze Alexandra Laignel-Lavastine ${ }^{85}$.

75 Ibidem, s. 161

${ }^{76}$ M. Zmierczak, Totalitaryzm - faszyzm - hitleryzm. Z historii sporów o genezę i istotę nazizmu w historiografii RFN, „Studia nad Faszyzmem i Zbrodniami Hitlerowskimi” XIV, 1991, „Acta Universitatis Wratislaviensis” 1169, s. 103-136.

${ }^{77}$ M. Zmierczak, Totalitaryzm czy totalitaryzmy? Klopoty z definiowaniem pojęcia, [w:] Totalitaryzm. Wybrane problemy teorii i praktyki, red. T. Wallas, Poznań 2003, s. 7-19.

${ }^{78}$ M. Zmierczak, Interwencjonizm, totalitaryzm czy ideologizacja gospodarki? Kilka uwag o własności i gospodarce w III Rzeszy, „Studia nad Faszyzmem i Zbrodniami Hitlerowskimi” XXVIII, 2005, „Acta Universitatis Wratislaviensis” 2750, s. 269-280.

${ }^{79}$ M. Zmierczak, Dyktatorzy totalitarni - problemy metodologiczne [materiały pokonferencyjne], [oddane do druku w Krakowie].

${ }^{80}$ M. Zmierczak, recenzja książki: P. Ayçoberry, La Question nazie. Les interprétations $d u$ national-socialisme, 1922-1975, „Przegląd Zachodni” XXXVII, 1981, nr 3/4, s. 180-184.

${ }^{81}$ M. Zmierczak, recenzja książki: Das Unrechtsregime. Internationale Forschung über den Faschismus, red. V.U. Büttner, „Przegląd Zachodni” XLIII, nr 3, s. 165-171.

${ }^{82}$ M. Zmierczak, recenzja książki: E. Jäckel, Hitlers Herrschaft. Vollzug einer Weltanschauung, „Dzieje Najnowsze” 1988.

${ }^{83}$ M. Zmierczak, recenzja książki: Totalitarian and Authoritarian Regimes in Europe. Legacies and Lessons from the Twentieth Century, red. J.W. Borejsza, K. Ziemer, M. Hułas, „Czasopismo Prawno-Historyczne" LIX, 2007, z. 2, s. 457-463.

${ }^{84}$ M. Zmierczak, recenzja książki: J. Sondel-Cedarmas, Nacjonalizm włoski. Geneza i ewolucja doktryny politycznej (1896-1923), „Czasopismo Prawno-Historyczne” LXV, 2013, s. 479-483.

${ }^{85}$ M. Zmierczak, recenzja książek: Vers un profil convergent des fascismes? „Nouveau consensus" et religion politique en Europe centrale, red. T. Sandu oraz A. Laignel-Lavastine, Cioran, Eliade, Ionesco: O zapominaniu faszyzmu. Trzech intelektualistów w dziejowej zawierusze, „Studia 
O pozycji naukowej prof. Zmierczak i znaczeniu jej dorobku w sferze badań nad faszyzmem i nazizmem świadczą wreszcie liczne prace redakcyjne i recenzje wydawnicze. Mimo że jest to forma działalności naukowej mniej widoczna, jednak nie może pozostać niedoceniona. $Z$ jednej bowiem strony należy pamiętać o ogromnym wysiłku i długim czasie, który trzeba poświęcić na redakcję tak monumentalnych dzieł, jak trzytomowy Hitler Iana Kershawa ${ }^{86}$ czy równie monumentalne Powojnie Tony'ego Judta. Z drugiej strony świadczy to o wysokiej pozycji naukowej i szacunku dla dorobku naukowego, gdyż do współpracy przy tego typu zadaniach zaprasza się jedynie najwybitniejszych specjalistów z danej dziedziny. Oprócz wcześniej wspomnianych publikacji wskazać należy redakcję naukową książek: R. Eatwella Faszyzm. Historia ${ }^{87}$; R.O. Paxtona Anatomia faszyzmu ${ }^{88}$; redakcję merytoryczną książki A. Lamberta Przegrane życie Ewy Braun ${ }^{89}$; redakcję naukową książki I. Kershawa Hitler, Niemcy i ostateczne rozwiąanie ${ }^{90}$ oraz recenzję wydawniczą wspomnianej wcześniej książki T. Judta Powojnie. Historia Europy od roku 1945 ${ }^{91}$, a także książek Pierwsza wojna Hitlera. Adolf Hitler, żotnierze pułku Lista i pierwsza wojna światowa Thomasa Webera ${ }^{92}$ i Hitlerland. Jak naziści zdobywali władzę? Andrew Nagorskiego ${ }^{93}$. Nie można również zapominać, że powyższe dzieła zaopatrzone są we wstępy i wprowadzenia autorstwa właśnie prof. Zmierczak ${ }^{94}$.

Tak jak badania nad faszyzmem i nazizmem wyewoluowały w badania nad totalitaryzmami, tak konsekwencją i niejako naturalną kontynuacją badań historii i ewolucji liberalizmu było zajęcie się w latach 90. przez prof. Zmierczak problematyką idei państwa prawa. Początkowo w ramach badań tej dziedziny myśli polityczno-prawnej prof. Zmierczak zajęła się historycznym rozwojem i zmianami pojmowania pojęcia Rechtsstaat w XIX- i XX-wiecznej niemieckiej filozofii prawa i kulturze politycznej. Temu poświęcony był artykuł pt. Kształtowanie się koncepcji państwa prawnego (na przykładzie niemieckiej myśli polityczno-prawnej) ${ }^{95}$ i jego

nad Faszyzmem i Zbrodniami Hitlerowskimi” 35, 2013, z. 3, „Acta Universitatis Wratislaviensis” 3523 , s. $123-128$.

${ }^{86}$ Redakcja naukowa książek I. Kershaw, Hitler, t. I, Poznań 2001; idem, Hitler, t. II, Poznań 2003.

${ }^{87}$ Redakcja naukowa książki R. Eatwell, Faszyzm. Historia, Poznań 1999.

${ }^{88}$ Redakcja naukowa książki R.O. Paxton, Anatomia faszyzmu, Poznań 2005.

${ }^{89}$ Redakcja merytoryczna książki A. Lambert, Przegrane życie Ewy Braun, Poznań 2006.

${ }^{90}$ Redakcja naukowa książki I. Kershaw, Hitler, Niemcy i ostateczne rozwiązanie, Poznań 2010.

${ }^{91}$ Recenzja wydawnicza książki T. Judt, Powojnie. Historia Europy od roku 1945, Poznań 2008.

92 Recenzja wydawnicza książki T. Weber, Pierwsza wojna Hitlera. Adolf Hitler, żotnierze pułku Lista i pierwsza wojna światowa, Poznań 2011.

93 Recenzja wydawnicza książki A. Nagorski, Hitlerland. Jak naziści zdobywali władzę?, Poznań 2012.

${ }^{94}$ Wstęp do wydań polskich: R. Eatwell, op. cit., s. 25-35; I. Kershaw, Hitler. 1889-1936: Hybris, Poznań 2001, s. XVII-XXXII; R.O. Paxton, op. cit., s. XI-XV; wstęp pt. Czy naoczny świadek najlepiej zna historię? Kilka słów wprowadzenia, [w:] A. Nagorski, op. cit., s. 17-25.

${ }_{95}$ M. Zmierczak, Kształtowanie się koncepcji państwa prawnego (na przykładzie niemieckiej myśli polityczno-prawnej), [w:] Demokratyczne państwo prawne, red. H. Rot, Wrocław 1992, „Acta Universitatis Wratislaviensis" 1457, s. 41-52. 
zmieniona wersja zatytułowana Ksztaltowanie się koncepcji państwa prawnego ${ }^{96}$. Swe zainteresowania prof. Zmierczak skierowała także w stronę Francji poprzez charakterystykę relacji współczesnego państwa prawnego i państwa socjalnego we Francji, czego wyrazem był tekst pt. Wspótczesna dyskusja nad pojęciem państwa prawa we Francji ${ }^{97}$. Rozważania o ewolucji pojęcia państwa prawa kontynuowała w opublikowanym w 2011 r. artykule O pojmowaniu państwa prawa - perspektywa historyczna ${ }^{98}$.

Kolejnym problemem badawczym w tej sferze był opis stosunków między współczesnym pojmowaniem pojęcia państwa prawa a demokracją i leżącą u jej podstaw zasadą suwerenności. W tym kontekście w swych pracach prof. Zmierczak podkreślała, że współcześnie państwo prawne powiązane jest z ideą ograniczenia suwerenności narodu. Pierwotnie idei państwa prawa postrzegana była głównie jako idea praworządności. Jednak $w$ toku ewolucji nastąpiły fundamentalne zmiany, które w swej istocie nawiązywały do ideologii liberalnej. Po pierwsze, zasada państwa prawa związała się z ideą, iż treści stanowionych norm prawnych powinny gwarantować jednostce określone prawa i wolności. Po drugie, $\mathrm{z}$ ograniczeniem zasady suwerenności narodu i odejścia od Rousseauwskiej całkowitej swobody stanowienia prawa. Ponadto zasada państwa prawa związana została z kształtem władzy publicznej, gdzie jako najlepsze rozwiązanie uznano zasadę podziału władzy. Wśród najważniejszych artykułów, które rozwijają te przemyślenia, wymienić należy: Liberalna krytyka demokracji jako źródto idei konstytucyjnej ${ }^{99}$; Koncepcja państwa prawnego jako ograniczenie władzy narodu $u^{100}$; Prawo - ograniczenie czy warunek wolności ${ }^{101}$; La question de la souveraineté de l'état et de la continuité du systeme juridique. Le cas polonaise ${ }^{102}$; Przedwojenna debata o podmiocie suwerenności we Francji - parlament czy naród? ${ }^{103}$

96 M. Zmierczak, Ksztattowanie się koncepcji państwa prawnego [wersja zmieniona], [w:] Polskie dyskusje o państwie prawa, red. S. Wronkowska, Warszawa 1995, s. 11-27.

${ }_{97}$ M. Zmierczak, Współczesna dyskusja nad pojęciem państwa prawa we Francji, [w:] Studia $z$ historii państwa, prawa i idei. Prace dedykowane Profesorowi Janowi Malarczykowi, red. A. Korobowicz, H. Olszewski, Lublin 1997, s. 501-511.

98 M. Zmierczak, O pojmowaniu państwa prawa - perspektywa historyczna, [w:] Spory wokót teorii i praktyki państwa prawa, red. G. Unicka, S. Wronkowska, Warszawa 2011, s. 11-27.

${ }_{99}^{9}$ M. Zmierczak, Liberalna krytyka demokracji jako źródło idei konstytucyjnej, [w:] Idee jako źródło instytucji politycznych i prawnych, red. L. Dubel, Lublin 2003, s. 129-144.

100 M. Zmierczak, Koncepcja państwa prawnego jako ograniczenie władzy narodu, [w:] Zasada demokratycznego państwa prawnego w Konstytucji RP, red. S. Wronkowska, Warszawa 2006, s. 73-89.

101 M. Zmierczak, Prawo - ograniczenie czy warunek wolności?, [w:] Prawne aspekty wolności. Zbiór studiów, red. E. Cała-Wacinkiewicz, D. Wacinkiewicz, Toruń 2008, s. 13-23.

$102 \mathrm{M}$. Zmierczak, La question de la souveraineté de l'état et de la continuité du systeme juridique. Le cas polonaise, [w:] Formation et décomposition des États en Europe au 20e siècle. Formation and Disintegration of European States in the 20th Century, red. A. Fleury et al., Bruksela 2012 , s. $149-168$.

${ }^{103}$ M. Zmierczak, Przedwojenna debata o podmiocie suwerenności we Francji - parlament czy naród?, [w:] Polska-Francja-Europa. Studia z dziejów Polski i stosunków międzynarodowych, red. J. Jurkiewicz et al., Poznań 2011, s. 671-679. 
W jednym z najważniejszych tekstów z tego cyklu (Koncepcja państwa prawnego jako ograniczenie władzy narodu, który znalazł się w cennym zbiorze pod redakcją sędziny Trybunału Konstytucyjnego — prof. Sławomiry Wronkowskiej-Jaśkiewicz, wydanym przez Wydawnictwo Sejmowe) prof. Zmierczak zajęła się rozważeniem relacji między pojęciami „państwo demokratyczne” $i$,państwo prawne”. Słusznie podkreśliła, że pojęć tych dotychczas ,nie wiązano w nierozłączną jedność, a dość wcześnie zauważono, że państwo demokratyczne niekoniecznie musi być państwem prawnym, i odwrotnie" 104 . Następnie wskazała, że podstawowym sporem w demokracji jest konflikt o to, co i jak może być regulowane „wolą narodu" lub wolą reprezentantów wybranych w drodze wyborów ${ }^{105}$. Podkreśliła, że

w naszym kręgu kulturowym panuje dość powszechna zgoda co do tego, iż demokracja nie oznacza wszechwładzy narodu, zaś gwarancją ograniczenia jest to, że ma być ona „państwem prawnym”, zaś ograniczenie treści stanowionych norm wynika z konstytucji, która wyznacza granice władzy ustawodawczej ${ }^{106}$.

Podkreślenia wymaga stwierdzenie, iż „współczesne państwo prawne oznacza państwo, w którym prawa człowieka wyznaczają granice dla władzy prawodawczej"107.

W podsumowaniu swego artykułu prof. Zmierczak zawarła uwagi, które w dzisiejszej sytuacji politycznej zdają się szczególnie cenne i mimo że były pisane ponad dekadę temu, nie tracą nic ze swej aktualności:

połączenie idei państwa demokratycznego z ideą państwa prawnego jest - co dostrzegano już wiele lat temu — próbą syntezy dwóch wartości, cenionych we współczesnym świecie: wolności politycznej, polegającej na tym, że naród podlega prawu, które sam tworzy, oraz wartości, które gwarantuje państwo prawa. W konsekwencji oznacza to ograniczenie swobody narodu-suwerena. Granice tej swobody wyznaczają trzy elementy: po pierwsze - prawa i wolności jednostki, w które władza prawodawcza nie może wkraczać, po drugie — zasady tworzenia prawa i systemu prawa, po trzecie - ograniczenia dotyczące zachowania zasadniczych zrębów ustroju państwa. Połączenie terminów „demokratyczny” i „prawnopaństwowy”, oznacza [...] ograniczenie demokracji przez poddanie jej rygorom prawa, którego najwyższym aktem jest konstytucja ${ }^{108}$.

Aby dopełnić obrazu zainteresowań naukowych prof. Zmierczak, warto dodać, że część swej pracy naukowej poświęciła samej nauce o doktrynach polityczno-prawnych oraz jej dydaktyce. Po pierwsze, prof. Zmierczak jest współautorem jednego z najlepszych i najbardziej popularnych podręczników do historii doktryn politycznych i prawnych w Polsce, którego zielona okładka jest znana zdecydowanej

\footnotetext{
${ }^{104}$ M. Zmierczak, Koncepcja..., s. 73.

105 Ibidem, s. 75.

106 Ibidem, s. 80.

107 Ibidem, s. 83.

108 Ibidem, s. 88.
} 
większości polskich prawników ${ }^{109}$. Po drugie, warto podkreślić ten wysiłek zwłaszcza w kontekście powracających co jakiś czas pomysłów reformy programów studiów prawniczych, które eliminowałyby przedmioty historyczno-prawne i niedogmatyczne. Tym bardziej na podkreślenie zasługują teksty prof. Zmierczak dotyczące dydaktyki doktryn polityczno-prawnych, m.in. Nauki historycznoprawne pośród dyscyplin prawniczych i w programach studiów ${ }^{110}$; Wydawnictwa źródlowe do nauki przedmiotów historyczno-prawnych ${ }^{111}$; Idee polityczne a ich prekursorzy ${ }^{112}$; Czy warto zajmować się ideologiami? Debaty o ideologii w drugiej polowie $X X$ wieku ${ }^{113}$. Pisząc o sferze dydaktycznej, nie można wreszcie zapomnieć, że prof. Zmierczak jest współautorem niezwykle popularnego podręcznika dla licealistów pt. Kompendium wiedzy o państwie, prawie $i$ spoleczeństwie $e^{114}$.

Ad extremum niezbędnym jest zaznaczyć, że oprócz wymienionym wyżej pól badawczych prof. Zmierczak — choć już mniej intensywnie — zajmowała się także innymi tematami naukowymi, wśród których wymienić należy zagadnienia idei narodowej ${ }^{115}$, problemy historii myśli ekonomicznej ${ }^{116}$, zagadnienia historii

${ }^{109}$ H. Olszewski, M. Zmierczak, Historia doktryn politycznych i prawnych, Poznań 1994.

${ }^{110}$ M. Zmierczak, Nauki historyczno-prawne pośród dyscyplin prawniczych $i$ w programach studiów, „Czasopismo Prawno-Historyczne” XLVII, 1996, z. 1-2, s. 79-91.

${ }^{111}$ E. Borkowska-Bagieńska, M. Zmierczak, Wydawnictwa źródlowe do nauki przedmiotów historyczno-prawnych, „Ruch Prawniczy, Ekonomiczny i Socjologiczny” XXXVIII, 1976, z. 2, s. $151-157$.

${ }^{112}$ M. Zmierczak, Idee polityczne a ich prekursorzy, [w:] Czas a trwanie idei politycznych i prawnych, red. K. Chojnicka, A. Citkowska-Kimla, W. Kozub-Ciembroniewicz, Kraków 2008, s. $19-30$.

113 M. Zmierczak, Czy warto zajmować się ideologiami? Debaty o ideologii w drugiej połowie XX wieku, [w:] Doktryny-historia-władza. Księga dedykowana prof. W. Kozubowi-Ciembroniewiczowi z okazji czterdziestolecia pracy naukowej, red. B. Szlachta, A. Citkowska-Kimla, M. Kiwior-Filo, Kraków 2009, s. 423-433.

114 Kompendium wiedzy o państwie, prawie $i$ społeczeństwie, red. M. Zmierczak, S. Wronkowska, Poznań 1993.

115 M. Zmierczak, Spory o naród po 1989 roku, [w:] Spoleczeństwo a władza. Ustrój, prawo, idee, red. J. Przygocki, M. Ptak, Warszawa 2012, s. 95-103; eadem, Nacjonalizm jako przedmiot badań historyka idei politycznych i prawnych, [w:] Doktryny polityczne i prawne u progu XXI wieku. Wybrane problemy badawcze, red. M. Maciejewski, M. Marszał, Wrocław 2002, s. 71-83; eadem, L'État et l'Église catholique romaine dans la pensée politique de Roman Dmowski et de la National-Démocratie, [w:] Église et États. France et Pologne XVe-XXe siecles, red. H. Martin, Rennes 1993, s. 99-108; eadem, Obraz Niemców i Niemiec w „Przegladzie Zachodnim”, „Przegląd Zachodni" 2014, nr 3 (352), s. 63-80; eadem, L'identité nationale des Polonais et Préambule de la Constitution de 1997, [w:] Religion et nation. Entre l'universel et particularismes. Actes du XIVe Collique Poznań-Strasbourg 28-29 Septembre 2006, red. M. Forycki, M. Serwański, Poznań 2008, s. 209-215.

${ }^{116}$ M. Zmierczak, Smith-Marks-Hayek-Keynes. Myśl ekonomiczna a myśl polityczno-prawna w dydaktyce doktryn polityczno-prawnych, [w:] Myślenie o polityce i prawie, red. J. Malczewski et al., Warszawa 2015, s. 357-368. 
Europy i historii ustroju państw europejskich ${ }^{117}$, ale też prawo natury po II wojnie światowej ${ }^{118}$.

Podsumowując rozważania o dorobku naukowym prof. Zmierczak, można przypomnieć, że za swoją rozprawę doktorską otrzymała w 1978 r. nagrodę Ministra Edukacji Narodowej II stopnia, jej rozprawa habilitacyjna została nagrodzona w 1989 r. przez Ministra Edukacji Narodowej i Dyrektora Instytutu Zachodniego, a sama prof. Zmierczak została odznaczona Złotym Krzyżem Zasługi i Krzyżem Kawalerskim Orderu Odrodzenia Polski. Jednak nie nagrody i ordery przesądzają o wielkiej wartości przemyśleń prof. Zmierczak. Po pierwsze, jej interpretacje — mimo iż do 1989 r. tworzone w systemie politycznym niesprzyjającym swobodzie badań naukowych — nic nie straciły na swej aktualności. Po drugie zaś, jej przemyślenia w dzisiejszym okresie kryzysu europejskiej demokracji liberalnej uzyskują kontekst, w którym mogą być na nowo odczytywane.

Prekursorstwo, badania obszarów dotychczas dziewiczych lub o fundamentalnym znaczeniu dla nauki prawa, benedyktyńska pracowitość wyrażająca się w badaniu ogromnej literatury źródłowej, ustalenia, które przetrwały próbę czasu i stanowią fundamenty myślenia na dany temat. Dorobek naukowy prof. Zmierczak z pewnością będzie służył przez długie lata wszystkim zgłębiającym tematykę ideologii i doktryn polityczno-prawnych.

\section{Bibliografia}

Borodziej W., Spory o faszyzm, „Polityka”, 2.09.1989, nr 35.

Constant B., Dzienniki poufne, Warszawa 1980.

Holzer J., Spory o istote faszyzmu (M. Zmierczak), „Jahrbücher für Geschichte Osteuropas” 39, 1991, z. 2.

Janasz T., recenzja książki: M. Zmierczak, Ideologia liberalna w II Cesarstwie, „Czasopismo Prawno-Historyczne" XXXI, 1979, z. 2.

Jonca K., recenzja książki: M. Zmierczak, Ideologia liberalna w II Cesarstwie, „Ruch Prawniczy, Ekonomiczny i Socjologiczny” XLI, 1979, z. 4.

${ }^{117}$ M. Zmierczak, Der Einfluss des Ersten Weltkriegs auf die Entwicklung des Volkerrechts, [w:] Traum vom Frieden-Utopie oder Realität?, red. E. Dácz, C. Griessler, H. Kovacs, Baden-Baden 2016, s. 151-166; eadem, Rapport général sur 'Les aléas de la démocratie', [w:] L'Europe au XXe siecle. Éléments pour un bilan, red. T. Schramm, Poznań 2000, s. 291-307; eadem, La Pologne et Locarno, [w:] Aristide Briand, la Société des Nations et l'Europe 1919-1932, red. J. Bariéty, J.R. Pitte, Strasbourg 2007, s. 117-129; eadem, Józef Pitsudski i ustrój Polski w latach 1926-1935, [w:] O prawie i jego dziejach ksieggi dwie. Studia ofiarowane Profesorowi Adamowi Lityńskiemu $w$ czterdziestopięciolecie pracy naukowej i siedemdziesięciolecie urodzin. Księga II, red. M. Mikołajczyk et al., Białystok-Katowice 2010, s. 453-459; eadem, Walter Bagehot zapomniany piewca ustroju brytyjskiego, [w:] Vetera novis augere. Studia i prace dedykowane Profesorowi Wacławowi Uruszczakowi, red. S. Grodziski et al., t. II, Kraków 2010, s. 1239-1246.

118 M. Zmierczak, Renesans koncepcji prawa natury po II wojnie światowej, [w:] Prawo natury w doktrynach polityczno-prawnych Europy, red. M. Zmierczak, Poznań 2006, s. 99-115. 
Kompendium wiedzy o państwie, prawie i społeczeństwie, red. M. Zmierczak, S. Wronkowska, Poznań 1993.

Kozub-Ciembroniewicz W., recenzja książki: M. Zmierczak, Spory o istotę faszyzmu, „Studia Historyczne" 1990, z. 2.

Kulesza W.T., recenzja książki: M. Zmierczak, Spory o istotę faszyzmu, „Państwo i Prawo” 1989, z. 12.

Olszewski H., Zmierczak M., Historia doktryn politycznych i prawnych, Poznań 1994.

Sobolewski M., recenzja książki M. Zmierczak Ideologia liberalna w II Cesarstwie, „Państwo i Prawo" 1979, z. 5.

Ziółek J., Z badań nad ideologia liberalna, „Przegląd Humanistyczny” XXIV, 1980, nr 2 (1730).

Zmierczak M., Autoportret faszyzmu. Refleksje na temat dziejów sporu o istotę faszyzmu, „Studia nad Faszyzmem i Zbrodniami Hitlerowskimi” XI, 1987, „Acta Universitatis Wratislaviensis” 815.

Zmierczak M., Czy naoczny świadek najlepiej zna historie? Kilka stów wprowadzenia, [w:] A. Nagorski, Hitlerland. Jak naziści zdobywali władzę?, Poznań 2012.

Zmierczak M., Czy warto zajmować się ideologiami? Debaty o ideologii $w$ drugiej polowie XX wieku, [w:] Doktryny-historia-władza. Księga dedykowana prof. W. Kozubowi-Ciembroniewiczowi z okazji czterdziestolecia pracy naukowej, red. B. Szlachta, A. Citkowska-Kimla, M. Kiwior-Filo, Kraków 2009.

Zmierczak M., Der Einfluss des Ersten Weltkriegs auf die Entwicklung des Volkerrechts, [w:] Traum vom Frieden-Utopie oder Realitat?, red. E. Dácz, C. Griessler, H. Kovacs, Baden-Baden 2016.

Zmierczak M., Faszyzm a problemy modernizacji. Krytyka amerykańskich teorii lat sześćdziesiątych, [w:] Faszyzm niemiecki z perspektywy pótwiecza. Materiaty i studia, red. A. Czubiński, Poznań 1985.

Zmierczak M., Faszyzm w dokumentach Międzynarodówki Komunistycznej z lat 1922-1943, „Studia nad Faszyzmem i Zbrodniami Hitlerowskimi” XI, 1986, „Acta Universitatis Wratislaviensis" 765 .

Zmierczak M., Filozofia i historiozofia w pismach Alfreda Rosenberga. Ze studiów nad ideologia nazizmu, „Studia Historica Slavo-Germanica” IX, 1980.

Zmierczak M., Francuscy liberałowie XIX wieku o centralizacji, decentralizacji i samorzadzie terytorialnym, [w:] Gospodarka, administracja, samorzad, red. H. Olszewski, B. Popowskia, „Prace WPiA” II, Poznań 1997.

Zmierczak M., Idee polityczne a ich prekursorzy, [w:] Czas a trwanie idei politycznych i prawnych, red. K. Chojnicka, A. Citkowska-Kimla, W. Kozub-Ciembroniewicz, Kraków 2008.

Zmierczak M., Ideologia liberalna w II Cesarstwie francuskim, Poznań 1978.

Zmierczak M., Ideologia liberalna w II Cesarstwie. Uwagi o konfliktach ideowych we Francji w latach 1852-1870, „Czasopismo Prawno-Historyczne” XXV, 1973, z. 2.

Zmierczak M., Ideologie totalitarne: faszyzm i narodowy socjalizm, [w:] Totalitaryzm a zachodnia tradycja, red. M. Kuniński, Kraków 2006.

Zmierczak M., Interwencjonizm, totalitaryzm czy ideologizacja gospodarki? Kilka uwag o własności i gospodarce w III Rzeszy, „Studia nad Faszyzmem i Zbrodniami Hitlerowskimi” XXVIII, 2005, „Acta Universitatis Wratislaviensis” 2750.

Zmierczak M., Jan Jakub Rousseau — rzecznik totalitaryzmu czy liberalnej demokracji?, „Czasopismo Prawno-Historyczne" XLI, 1989, z. 2.

Zmierczak M., Jednostka a Volk w ideologii nazizmu, [w:] Studia z dziejów myśli politycznej w Niemczech w XIX i XX wieku, red. H. Olszewski, Poznań 1982.

Zmierczak M., John Stuart Mill o prawie wyborczym w demokracji - refleksje z perspektywy XXI wieku, „Gdańskie Studia Prawnicze” XXVII, 2012.

Zmierczak M., Józef Pitsudski i ustrój Polski w latach 1926-1935, [w:] O prawie i jego dziejach księgi dwie. Studia ofiarowane profesorowi Adamowi Lityńskiemu w czterdziestopięciolecie

Studia nad Autorytaryzmem i Totalitaryzmem 38, nr 4, 2016

(C) for this edition by CNS 
pracy naukowej i siedemdziesięciolecie urodzin. Ksiega II, red. M. Mikołajczyk, J. Ciągwa, P. Fiedorczyk, A. Stawarska-Rippel, T. Adamczyk, A. Drogoń, W. Organiściak, K. Kuźmicz, Białystok-Katowice 2010.

Zmierczak M., Kilka uwag o objaśnianiu faszyzmu w polskich podręcznikach szkolnych z lat 19451995, „Studia nad Faszyzmem i Zbrodniami Hitlerowskimi” XX, 1997, „Acta Universitatis Wratislaviensis" 1943.

Zmierczak M., Koncepcja państwa prawnego jako ograniczenie władzy narodu, [w:] Zasada demokratycznego państwa prawnego w Konstytucji RP, red. S. Wronkowska, Warszawa 2006.

Zmierczak M., Krytyka demokracji w ideologii Adolfa Hitlera, „Studia nad Faszyzmem i Zbrodniami Hitlerowskimi” XXXII, 2010, „Acta Universitatis Wratislaviensis” 3240.

Zmierczak M., Ksztaltowanie się koncepcji państwa prawnego (na przykładzie niemieckiej myśli polityczno-prawnej), [w:] Demokratyczne państwo prawne, red. H. Rot, Wrocław 1992.

Zmierczak M., Ksztaltowanie się koncepcji państwa prawnego [wersja zmieniona], [w:] Polskie dyskusje o państwie prawa, red. S. Wronkowska, Warszawa 1995.

Zmierczak M., L'identité nationale des Polonais et Préambule de la Constitution de 1997, [w:] Religion et nation. Entre l'universel et particularismes. Actes du XIVe Collique Poznań-Strasbourg 28-29 Septembre 2006, red. M. Forycki, M. Serwański, Poznań 2008.

Zmierczak M., La Pologne et Locarno, [w:] Aristide Briand, la Société des Nations et l'Europe 1919-1932, red. J. Bariéty, J.R. Pitte, Strasbourg 2007.

Zmierczak M., La question de la souveraineté de l'état et de la continuité du systeme juridique. Le cas polonaise, [w:] Formation et décomposition des États en Europe au 20e siècle. Formation and Disintegration of European States in the 20th Century, red. A. Fleury, F. Knipping, D. Kovac, T. Schramm, Bruksela 2012.

Zmierczak M., Leonard Trelawney Hobhouse - prekursor liberalizmu społecznego, „Gdańskie Studia Prawnicze" XX, 2008.

Zmierczak M., L'État et l'Église catholique romaine dans la pensée politique de Roman Dmowski et de la National-Démocratie, [w:] Église et États. France et Pologne XVe-XXe siecles, red. H. Martin, Rennes 1993.

Zmierczak M., Liberalna krytyka demokracji jako źródło idei konstytucyjnej, [w:] Idee jako źródto instytucji politycznych i prawnych, red. L. Dubel, Lublin 2003.

Zmierczak M., Nacjonalizm jako przedmiot badań historyka idei politycznych i prawnych, [w:] Doktryny polityczne i prawne u progu XXI wieku. Wybrane problemy badawcze, red. M. Maciejewski, M. Marszał, Wrocław 2002.

Zmierczak M., Nauki historyczno-prawne pośród dyscyplin prawniczych $i$ w programach studiów, „Czasopismo Prawno-Historyczne” XLVII, 1996, z. 1-2.

Zmierczak M., Obraz Niemców i Niemiec w „Przeglądzie Zachodnim”, „Przegląd Zachodni” 2014, nr 3 (352).

Zmierczak M., O pojmowaniu państwa prawa - perspektywa historyczna, [w:] Spory wokót teorii i praktyki państwa prawa, red. G. Unicka, S. Wronkowska, Warszawa 2011.

Zmierczak M., O rozumieniu terminu, faszyzm" w powojennej Polsce, [w:] Historia prawa. Historia kultury. Liber memorialis Vitoldo Maisel dedicatus, red. E. Borkowska-Bagieńska, H. Olszewski, Poznań 1994.

Zmierczak M., O stanie i kierunkach rozwoju marksistowskich badań nad faszyzmem. Kilka uwag na marginesie zbioru ,Faschismusforschung. Positionen, Probleme, Polemik”, „Przegląd Zachodni" XXXVI, 1980, nr 5/6.

Zmierczak M., Pojęcie „socjalizm” $i$,narodowy socjalizm” w mowach agitacyjnych Hitlera $w$ latach 1925-1933, „Studia nad Faszyzmem i Zbrodniami Hitlerowskimi” XXIX, 2007, „Acta Universitatis Wratislaviensis" 2962.

Zmierczak M., Pozytywizm prawniczy a prawnicy i prawo w Trzeciej Rzeszy — powojenna dyskusja niemieckich historyków i teoretyków prawa o przyczynach upadku prawa w czasach nazizmu,

Studia nad Autorytaryzmem i Totalitaryzmem 38, nr 4, 2016

(C) for this edition by CNS 
„Studia nad Faszyzmem i Zbrodniami Hitlerowskimi” XXIV, 2001, „Acta Universitatis Wratislaviensis" 2214.

Zmierczak M., Prawo - ograniczenie czy warunek wolności?, [w:] Prawne aspekty wolności. Zbiór studiów, red. E. Cała-Wacinkiewicz, D. Wacinkiewicz, Torun 2008.

Zmierczak M., Prawo w III Rzeszy a standardy kultury prawnej, [w:] Nam hoc natura aequum est, red. A. Madeja, H. Olszewski, Toruń 2012.

Zmierczak M., Prominent Liberals' Attitude towards Democracy, [w:] Liberalism. Yesterday and Today, red. K. Kujawińska-Courtney, R.M. Machnikowski, Łódź 1998.

Zmierczak M., Przedwojenna debata o podmiocie suwerenności we Francji - parlament czy naród?, [w:] Polska-Francja-Europa. Studia z dziejów Polski i Stosunków Międzynarodowych, red. J. Jurkiewicz, M. Forycki, A. Jakuboszczak, I. Kraszewski, Poznań 2011.

Zmierczak M., Przemówienia polityczne Hitlera przed zdobyciem władzy (1925-1933), „Rocznik Nauk Politycznych" 2006, nr 1 (9).

Zmierczak M., Rapport général sur 'Les aléas de la démocratie', [w:] L'Europe au XXe siecle. Éléments pour un bilan, red. T. Schramm, Poznań 2000.

Zmierczak M., recenzja książki: P. Ayçoberry, La Question nazie. Les interprétations du national-socialisme, 1922-1975, „Przegląd Zachodni” XXXVII, 1981, nr 3/4.

Zmierczak M., recenzja książki: A. Czarnota, John Stuart Mill. Studium z dziejów liberalizmu politycznego, „Czasopismo Prawno-Historyczne” XXXIX, 1987, z. 2.

Zmierczak M., recenzja książki: Das Unrechtsregime. Internationale Forschung über den Faschismus, red. V.U. Büttner, „Przegląd Zachodni” XLIII, nr 3.

Zmierczak M., recenzja książki: E. Jäckel, Hitlers Herrschaft. Vollzug einer Weltanschauung, „Dzieje Najnowsze” 1988.

Zmierczak M., recenzja książki: A. Laignel-Lavastine, Cioran, Eliade, Ionesco: O zapominaniu faszyzmu. Trzech intelektualistów w dziejowej zawierusze, „Studia nad Faszyzmem i Zbrodniami Hitlerowskimi” 35, 2013, z. 3, „Acta Universitatis Wratislaviensis” 3523.

Zmierczak M., recenzja książki: B. Sobolewska, M. Sobolewski, Liberalizm. Myśl polityczna XIX i XX wieku, „Czasopismo Prawno-Historyczne” XXXI, 1979, z. 2.

Zmierczak M., recenzja książki: J. Sondel-Cedarmas, Nacjonalizm włoski. Geneza i ewolucja doktryny politycznej (1896-1923), „Czasopismo Prawno-Historyczne” LXV, 2013.

Zmierczak M., recenzja książki: W. Szyszkowski, Benjamin Constant. Doktryna polityczno-prawna na tle epoki, „Państwo i Prawo” 1984, z. 11.

Zmierczak M., recenzja książki: A. de Tocqueville, Dawny ustrój i rewolucja, „Czasopismo Prawno-Historyczne" XXIII, 1971, z. 2.

Zmierczak M., recenzja książki: Totalitarian and Authoritarian Regimes in Europe. Legacies and Lessons from the Twentieth Century, red. J.W. Borejsza, K. Ziemer, M. Hułas, „Czasopismo Prawno-Historyczne" LIX, 2007, z. 2.

Zmierczak M., recenzja książki: Tocquevillian ideas. Contemporary European Perspectives, red. Z. Rau, M. Tracz-Tryniecki, „Czasopismo Prawno-Historyczne” LXVI, 2014.

Zmierczak M., recenzja książki: V Republika Francuska. Idee, konstytucja, interpretacje, red. K.M. Ujazdowski, „Czasopismo Prawno-Historyczne” LXIII, 2011, z. 2.

Zmierczak M., recenzja książki: Vers un profil convergent des fascismes? „Nouveau consensus” et religion politique en Europe centrale, red. T. Sandu, „Studia nad Faszyzmem i Zbrodniami Hitlerowskimi” 35, 2013, z. 3, „Acta Universitatis Wratislaviensis” 3523.

Zmierczak M., Refleksje o prawie cywilnym w totalitarnym ustroju III Rzeszy, [w:] Księga jubileuszowa Profesora Tadeusza Smyczyńskiego, red. M. Andrzejewski et al., Torun 2008.

Zmierczak M., Renesans koncepcji prawa natury po II wojnie światowej, [w:] Prawo natury w doktrynach polityczno-prawnych Europy, red. M. Zmierczak, Poznań 2006.

Studia nad Autorytaryzmem i Totalitaryzmem 38, nr 4, 2016

(C) for this edition by CNS 
Zmierczak M., Socjaldemokraci a faszyzm. Uwagi o socjaldemokratycznych teoriach faszyzmu z lat 1922-1945, „Studia nad Faszyzmem i Zbrodniami Hitlerowskimi” XII, 1987, „Acta Universitatis Wratislaviensis" 923.

Zmierczak M., Spory historyków i politologów o ustrój Trzeciej Rzeszy, [w:] Studia z historii ustroju i prawa. Ksiega dedykowana Profesorowi Jerzemu Walachowiczowi, red. H. Olszewski, Poznań 2002.

Zmierczak M., Spory o Adolfa Hitlera w najnowszej literaturze, „Studia nad Faszyzmem i Zbrodniami Hitlerowskimi” XXVI, 2003, „Acta Universitas Wratilsaviensis” 2532.

Zmierczak M., Spory o istote faszyzmu. Dzieje i krytyka, Poznań 1988.

Zmierczak M., Spory o naród po 1989 roku, [w:] Społeczeństwo a władza. Ustrój, prawo, idee, red. J. Przygocki, M. Ptak, Warszawa 2012.

Zmierczak M., Spory o role i miejsce Adolfa Hitlera w historii Niemiec, „Przegląd Zachodni” XLVIII, 1992, z. 4.

Zmierczak M., Totalitaryzm - faszyzm - hitleryzm. Z historii sporów o genezę i istotę nazizmu w historiografii RFN, „Studia nad Faszyzmem i Zbrodniami Hitlerowskimi” XIV, 1991, „Acta Universitatis Wratislaviensis" 1169.

Zmierczak M., Totalitaryzm czy totalitaryzmy? Kłopoty z definiowaniem pojęcia, [w:] Totalitaryzm. Wybrane problemy teorii i praktyki, red. T. Wallas, Poznań 2003.

Zmierczak M., Walter Bagehot - zapomniany piewca ustroju brytyjskiego, [w:] Vetera novis augere. Studia i prace dedykowane Profesorowi Wactawowi Uruszczakowi, red. S. Grodziski, D. Malec, A. Karabowicz, M. Stus, t. II, Kraków 2010.

Zmierczak M., Wspótczesna dyskusja nad pojęciem państwa prawa we Francji, [w:] Studia z historii państwa, prawa i idei. Prace dedykowane Profesorowi Janowi Malarczykowi, red. A. Korobowicz, H. Olszewski, Lublin 1997.

Zmierczak M., Wstęp do wydania polskiego, [w:] R. Eatwell, Faszyzm. Historia, Poznań 1999.

Zmierczak M., Wstep do wydania polskiego, [w:] I. Kershaw, Hitler. 1889-1936: Hybris, Poznań 2001.

Zmierczak M., Wstęp do wydania polskiego, [w:] R.O. Paxton, Anatomia faszyzmu, Poznań 2005.

Zmierczak M., Borkowska-Bagieńska E., Wydawnictwa źródtowe do nauki przedmiotów historyczno-prawnych, „Ruch Prawniczy, Ekonomiczny i Socjologiczny” XXXVIII, 1976, z. 2.

Zmierczak M., Olszewski H., Faszyzm a prawo, „Ruch Prawniczy, Ekonomiczny i Socjologiczny” XLIV, 1982, z. 3.

Zmierczak M., Smith-Marks-Hayek-Keynes, Myśl ekonomiczna a myśl polityczno-prawna $w d y$ daktyce doktryn polityczno-prawnych, [w:] Myślenie o polityce i prawie, red. J. Malczewski, M. Jaskólski, A. Czarnecka, I. Barwicka-Tylek, Warszawa 2015.

\section{VIVERE EST COGITARE. SKETCH ON THE ACADEMIC ACHIEVEMENTS OF PROFESSOR MARIA ZMIERCZAK}

\section{Summary}

The aim of the paper is presentation of the most significant scientific interests of a full professor and post-doctorate degree Maria Zmierczak, reputed and prominent scholar of history of political and legal doctrines, for many years head of the Chair of Political and Legal Doctrines and Philosophy on the Faculty of Law and Administration at Adam Mickiewicz University in Poznań.

The scientific interests of Professor Maria Zmierczak include the classical political doctrines of 19th and 20th century and chosen legal doctrines of 20th century. Among the first ones the most 
compelling is the research on history and the evolution of liberalism and the study on totalitarianism and fascism. The other issues analyzed by Professor Maria Zmierczak consist of the research on the Renaissance of the natural law after the Second World War and the study on the rule of law.

Keywords: Maria Zmierczak, liberalism, fascism, nazism, totalitarianism, rule of law, political and legal doctrines.

Michał Urbańczyk

michal.urbanczyk@amu.edu.pl 